\title{
The Effect of Professionalism, ESQ and Locus of Control on Acceptance Dysfunctional Behavior with Performance of Internal Auditor as an Intervening Variable
}

\section{Shelly Febriana Kartasari, Heru Tjaraka, and Erina Sudaryati}

Universitas Airlangga, Gubeng, Kota SBY, Jawa Timur 60115, Indonesia

\section{Abstract}

The purpose of this study is to determine the influences of professionalism, Emotional Spiritual Quotient (ESQ), and Locus of Control on Dysfunctional Behavior with the Performance of Internal auditor as an intervening variable. The study is conducted in State Development Audit Agency, South Sumatra Province. This study has employed associative research methods to determine the relationship of correlation or causal

Corresponding Author: Shelly Febriana Kartasar shellyfebrianakartasari@ unsri.ac.id

Received: 29 August 2018 Accepted: 18 September 2018 Published: 11 November 2018 Publishing services provided by Knowledge

(c) Shelly Febriana Kartasari et al. This article is distributed under the terms of the

mons Attribution License, which permits unrestricted use and redistribution provided that the original author and source are credited.

Selection and Peer-review under the responsibility of the ICOI-2018 Conference Committee.

\section{G OPEN ACCESS} relationship between variables. The sampling technique used is saturated sample or census for 110 internal auditors with varying degrees, but with just 52 eligible respondents processed and tested further. The analysis of data used a structural equation model with a Partial Least Square approach coupled with Smart PLS Software 3.o. The results showed that the professionalism, ESQ, and locus of control are directly related to dysfunctional behavior, and to the performance of internal auditor as a variable support for dysfunctional behaviors' internal auditor in South Sumatra. In effect, high professionalism, ESQ, and Locus of Control could lead to effective performance for internal auditors and, hence, deter fraud.

Keywords: professionalism, ESQ (Emotional Spiritual Quotient), locus of control, performance, reception dysfunctional behavior

\section{Introduction}

According to Mardiasmo, there are several weaknesses in government audit: (1) There is unavailability of an adequate performance indicator used as basic determination of government performance measurement by Indonesia's central government and local government. This condition generally occurs in public organizations because their output, for example, public services can't be measured easily. (2) The audit organization structure problems of central government and local government in Indonesia are 
overlapping. This condition makes the audit process in Indonesia inefficient and ineffective. Audit quality is determined by the appropriate process and must be followed with the personal control of the auditor. Professionalism has a significant influence on audit quality. That is, to produce quality audit reports, auditors are required to be professional. The auditor shall carry out his work by complying with the applicable code of conduct in order for the resulting audit report to explain the conditions fully and, of course, improve the quality of the content of the audit report. The results of this study are consistent with the research conducted by Lavin (1976), Ussahawanitchakit (2008) and Baotham (2007) stating that professionalism is significantly influential to audit quality.

Research in the control system states that excessive control systems will lead to conflict and dysfunctional behavior (Otley \& Pierce, 1996). According to Jansen and Glinow (1985), individual behavior is a reflection of the personality side while situational factors that occur at that time will encourage someone to make a decision. From that opinion, it can be concluded that dysfunctional audit behavior can be caused by the personal characteristics factor from the auditor (internal factor) and the situational factor when doing the audit (external factor).

The personal characteristics that influence the acceptance of dysfunctional behavior include locus of control [6], and Employee Performance (Gable \& De Angelo, 1994; [6]). Past studies have shown a strong and positive relationship between the individual's external locus of control with a desire or intent to use deception or manipulation to obtain personal goals. Solar and Bruehl (1971) suggest that individuals performing a performance under the expectations of their superiors will tend to engage in dysfunctional behaviors because they do not see themselves as achieving the goals necessary to survive in a company through their own efforts; therefore, dysfunctional behavior is considered necessary in this situation.

Basically, humans are created by bringing into play the element of intelligence. Initially, intelligence was understood by many as intelligence quotient, in accordance with the development of human knowledge, then other types of intelligence were found through empirical and longitudinal research by academics and practitioners of psychology, namely emotional intelligence (emotional quotient) and spiritual intelligence (spiritual quotient). These three forms of intelligence cannot stand alone for success in work and life. Plenary success is only possible if one is able to best use these three intelligences, balance them and apply them in life. For workers in any organizational environment these three forms of intelligence are an absolute must, 
career success is not only owned by high-performing employees, but everyone can achieve career success and secure the best place to work.

Personal characteristics influence reception dysfunction behavior like professionalism (Baotham, 2007; Lavin, 1976; Ussahawanitchakit, 2008), locus of control [6], and employee performance $[6,7]$. Professional attitudes and actions are present in all fields and professions. When performing audit, professional auditors are expected to apply an audit system which fulfills the standard requirement decided by the organization. In addition, they have to minimize dysfunctional behavior. Idris (2011) concludes that professionalism has significant influence to dysfunctional behavior. The higher an auditor's professionalism, the lower the dysfunctional behavior. Previous studies have shown strong and positive relationships of individual locus of control with desires to manipulate in order to gain personal profit. It means the higher the external individual locus of control, the lower the dysfunctional behavior ([6]; Solar \& Bruehl, 1971).

ESQ-related research is important because Indonesia still holds the title as the fifth most corrupt country in the world.

The State Development Audit Agency as an internal auditor has the scope, duties, responsibilities and authority to conduct internal supervision on government institutions, institutions and / or other parties in which there are state interests in accordance with legislation. Internal supervision is conducted to provide reasonable assurance on the obedience, efficiency, efficiency and effectiveness of the achievement of the purpose of organizing the tasks and functions of government agencies, providing early warning and improving the effectiveness of risk management in the implementation of duties and functions of government agencies as well as to maintain and improve the quality of governance of the tasks and functions of government agencies. Therefore, this study will examine the relationship of personal characteristics, which consist of ESQ and locus of control, as public confidence in the performance of the government needs to be restored with professional practice running the government oversight.

According to the aforementioned explanation, this research is entitled 'The Effect of Professionalism, ESQ and Locus of Control on Reception of Dysfunctional Behavior with Performance of INGIA as an Intervening Variable'.

\section{Literature Review}




\subsection{Acceptance of dysfunctional behavior}

SAS No. 82 in Donnelly et al. (2003) stated that the attitude of the auditor receives dysfunctional behavior as an indicator of the actual dysfunctional behavior. Audit Dysfunctional Behavior is a reaction to the environment [6]. Some dysfunctional behaviors that harm the quality of the audit are: underreporting of time, premature sign off, and altering / replacement of audit procedures. Underreporting of time causes poor personal decisions to cover the needs of the budget revision, and resulting in time pressure for audit in the future not in the present. Premature sign-off (PMSO) is a condition that indicates the auditor to stop one or more of the audits required in audit procedures without replacing the other step (Marxen, 1990 as cited in Cristina, 2003). Graham (1985 as cited in Shapero et al., 2003) concluded that an audit failure is often caused by the elimination of important audit procedures of the audit procedure and is not done adequately for some items. Altering / replacing of the audit procedure is the replacement of the audit procedures that should be set out in auditing standards.

\subsection{Professionalism}

The professionalism concept is used to measure how professionals look at their profession as reflected in their attitudes and behaviors. Hall (1968) said there is a reciprocal relationship between attitudes and behavior. An auditor is responsible for planning and carrying out an audit to obtain reasonable assurance about whether financial statements are free from material misstatement, whether caused by error or fraud. Previts (1985) describes the characteristics as descriptive of professionalism, such as a definable body of knowledge, individuality (decisions are personal, not collective), ethical constraints (self-discipline), altruism (placing the wellbeing of others above self-interest), and judgment (decision-making in the face of uncertainty). Also, he cites that independence, skills and legality, professionalism and adaptability play major roles in the attested function, such as an audit. Brown, Morris, and Wilder (2006) stated that audit professionalism describes a set of obligations for professional behavior in an audit that the auditors should perform to demonstrate trustworthiness and maintain public interest, such as responsibility, integrity, objectivity and independence, and due care. Catanach and Walker (1999) suggest that professional conduct positively affects audit quality. Professional requirements demanded by independent auditors are to have the education and practicing experience as an independent auditor. Independent 
auditors are also responsible for professionalism and the responsibility to comply with standards accepted by practitioners of his professional colleagues.

\subsection{ESQ}

Emotional Quotient (EQ) is the ability to feel, understand and effectively apply the power and sensitivity of emotions as a source of energy, information, connections and human influence (Cooper \& Sawaf, 1998). Salovey and Mayer define emotional intelligence as the ability to recognize feelings, reach and awaken feelings to help the mind, understand the feeling and meaning, and control the depth of feeling that fosters emotional and intellectual responses (Stein \& Book, 2002). Research using Baron EQ EQ EQ-i divides into five scales: intrapersonal: self-esteem, emotional selfawareness, assertiveness, independence, self-actualization; interpersonal: empathy, social responsibility, interpersonal relations; the scale of adjustment capabilities: test reality, flexibility, problem solving; stress management scale: stress resistance, control impulses (impulse); general mood scale: optimism, happiness (Stein \& Book, 2002).

Zohar and Marshall include aspects of the context of value as a part of the process of thinking / intelligence in meaningful life; for this they use the term spiritual intelligence (Spiritual Quotient / SQ) (Zohar and Marshall, 2000). Indications of spiritual intelligence in their view include the ability to live the values and meanings, have self-awareness, be flexible and adaptive, tend to look at things holistically, as well as the tendency to seek answers fundamental to situations of one's life and that of others. Spiritual Quotient according to secular thinking has not been able to provide a comprehensive meaning to being human.

\subsection{Locus of Control}

Some individuals believe that they can control what happens to them, while others believe that what happens to them is controlled by outside forces, such as luck and opportunities. Locus of control is a 'generalized belief that a person can or cannot control his own destiny or a person's perspective on the events whether he able to control behavior that happened to him or not' (Rotter, 1966). Brownell (1982) suggested that locus of control is how far one accepts personal responsibility for what happens to them. Furthermore, Robbins (2003) defined locus of control as a person's perception of his fate source. 


\subsection{Employee performance}

Assessment of employee performance is a useful tool, not only to evaluate the work, but also to develop and motivate all the existing human resources within the organization. Basically, the work assessment can be considered as a tool to verify that the individual meets the performance standards that have been set. According to Lee (2000), people will like the job if they are motivated for the job, and, psychologically, that the work is done means there is a sense of responsibility for the work performed and their knowledge of the work so that the work will improve the motivation, satisfaction and performance.

Locus of control plays a role in motivation and could reflect different motivations and different performances. Internal locus of control is likely to be more successful in the career of those with external locus of control, as they tend to have higher levels of employment, faster promotion and earn more money. In addition, those with internal locus of control have higher satisfaction with their work and seem better able to withstand stress than those having external locus of control (Baron \& Greenberg, 1990 as cited in Puji, 2005). Rotter (1990 as cited in [8]) explains that those with external locus of control generally perform better when restraint is imposed upon them. Hyatt and Prawitt (2001) prove that the locus of control may impact on the performance audit of the internal auditor and the external auditor.

There are some previous studies which address this kind of research as follows: 1). Armansyah (2002) conducted research using ESQ, which consists of Intelligence Quotient, Emotional Quotient, Spiritual Quotient and working attitudes as variables. Literature review was using as tool of analysis. The result showed that three components of ESQ, which consist of Intelligence Quotient, Emotional Quotient and Spiritual Quotient, need to be researched frequently in order to increase working attitudes. 2). Gable and Dangello (2003) used locus of control, Machiavellianism and managerial performance as their variables. They conducted the research by using AMOS. The result showed that locus of control influences managerial performance. In addition, Machiavellianism influenced directly to managerial performance.

\section{Research Method and Result}

The population in this study is that of internal auditors who work at the State Development Audit Agency at South Sumatra Province. The population of this study was 110 internal auditor auditors with varying degrees of auditors, but the appropriate 
curtailers for the test were only 52 or $47.27 \%$ of the eligible population processed and tested further. In this study, analysis of data used the approach of Partial Least Square (PLS). PLS is a model equation of Structural Equation Modeling (SEM) based on components or variants. According to Ghozali (2006), PLS is an alternative approach that shifts covariance-based SEM approaches to become variants-based. General covariance-based SEM tests causality / PLS, whereas theory is more predictive models. PLS is a powerful analytical method (Ghozali, 2006), because it is not based on many assumptions Parameter estimates obtained by the PLS can be categorized into three. First, the weight estimate is used to create the latent variable scores. Second, by reflecting the estimated path (path estimate) that connects between the latent variables and latent variables and indicators (loading). Third, with regard to the means and location parameters (regression constant value) for the indicators and the latent variables. To obtain these estimates, PLS uses a three-stage process of iteration and each iteration stage produces estimates. The first stage produces weight estimate, the second stage of the model yields an estimate for the inner and outer models, and the third phase generates means and location estimation (Ghozali, 2006).

\subsection{Hypothesis}

Professional behavior is a reflection of professional attitude, and vice versa (Kalbers \& Fogarty, 1995). As a consequence, professionalism is likely to have a positive relationship with audit quality. Audit quality is determined by the appropriate process and must be followed and is under the personal control of the auditor. Professionalism has a significant influence on audit quality. Lavin (1976), Baotham (2007) and Ussahawanitchakit (2008) stated that professionalism significantly influences audit quality. Audit quality is a performance of internal auditor. Based on the aforementioned description, the hypothesis built is:

$\mathrm{H}_{1}$ : professionalism influences internal auditor's performance

Emotional Quotient (EQ) is the ability to sense, understand and effectively apply the power and emotional sensitivity as a source of energy, information, connections and human influences (Cooper \& Sawaf, 1998). Salovey and Mayer define emotional intelligence as the ability to recognize feelings, reach out and arouse feelings to help the mind, understand its feelings and meaning, and control feelings deeply so as to foster emotional and intellectual development (Stein \& Book 2002). Based on the aforementioned description, the hypothesis built is: 
$\mathrm{H}_{2}$ : ESQ influences internal auditor's performance

Locus of control affects the acceptance of audit dysfunctional behavior as well as the actual dysfunctional behavior of audit and job satisfaction ([6]; Reed et al., 1994). Rotter's research (1990 as cited in [8]) explains that those with external locus of control generally perform better when control is imposed on them. Based on the aforementioned description, the hypothesis built is:

$\mathrm{H}_{3}$ : locus of control influences internal auditor's performance

$\mathrm{H}_{4}$ : professionalism influences dysfunctional behavior

$\mathrm{H}_{5}$ : ESQ influences dysfunctional behavior

Research conducted by Gable and Dangello (1994) shows a strong positive influence between the external locus of control of the individual with the intention to pass through manipulative action or deviant action. The results of this study are in line with research conducted by Solar and Bruehl (1971) and Comer (1985). Based on the aforementioned description, the hypothesis built is:

$\mathrm{H}_{6}$ : locus of control influences dysfunctional behavior

$\mathrm{H}_{7}$ : internal auditor's performance influences dysfunctional behavior

$\mathrm{H}_{8}$ : professionalism, ESQ and locus of control influence dysfunctional behavior through internal auditor's performance as an intervening variable

\subsection{Analysis and result}

The following results display PLS Algorithm Based on the results of the PLS Algorithm and it can be seen that there is a construct loading factor of less value or below 0.5 . Constructs with a loading factor value below 0.5 should be dropped because it is not in accordance with the provisions and will affect the value's composite reliability. The following are the results of the PLS Algorithm after the drop. Results of analysis using PLS (Partial Least Square) obtained the following results:

Based on the aforementioned statistical data analysis, the results are that professionalism has positive influence to performance of an internal auditor. Otherwise, professionalism has negative influence to dysfunctional behavior. It means the higher the professionalism of an internal auditor, the lower their dysfunctional behavior.

ESQ has positive influence on acceptance of dysfunctional audit behavior, meaning that the higher the ESQ, the higher the acceptance of dysfunctional audit behavior. This 


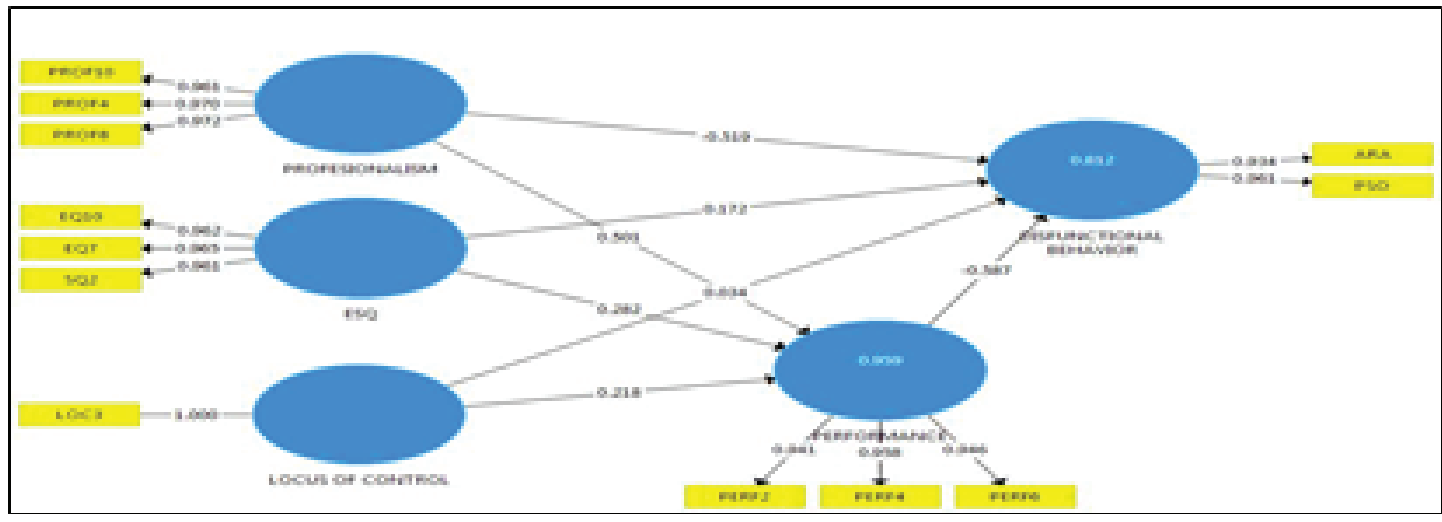

Figure 1: Structural model.

\begin{tabular}{|c|c|c|c|c|c|c|c|}
\hline \multicolumn{8}{|l|}{ Path Coetficients } \\
\hline \multirow[t]{2}{*}{ (1) Men, SroeV, T.Values, - } & $\square$ Centider & ince betervats & , $\square c$ & Cenfidence imenvals 8 . & Samples & Expont to clipbound [ & Co Cosy to cliptoand \\
\hline & \multicolumn{3}{|c|}{ Original Sampl. } & - Sample Mean L St Se & indard Oevia. & TShativitica 00_ & D Valuen \\
\hline \multirow{2}{*}{\multicolumn{2}{|c|}{ 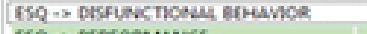 }} & & 0472 & 0.160 & $a n n$ & 0.9972 & Q.34 \\
\hline ESQ ... nisfokmanke & & & 0.282 & 0.234 & 0004 & 3017 & 0.003 \\
\hline \multirow{2}{*}{\multicolumn{2}{|c|}{ LOCUS of Coevthos -> DESFunectno- }} & & 0.034 & o. & a.19 & 0.20 & $0 . m$ \\
\hline & & & 0.213 & $0 . m$ & coss & 3607 & 0.000 \\
\hline \multicolumn{2}{|c|}{ 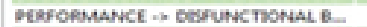 } & & 0.058 & -8505 & $a \times 2$ & 2306 & 0.004 \\
\hline \multicolumn{2}{|c|}{ 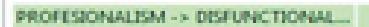 } & & 0.319 & -0.500 & 0.170 & 30030 & 0.002 \\
\hline \multicolumn{2}{|c|}{ PROFESIONULASM - > FESCEMCANCR } & & 0.50 t & 0.456 & 0.000 & 6.200 & 0.000 \\
\hline
\end{tabular}

Figure 3. Indirect Effect

\section{Indirect Effects}

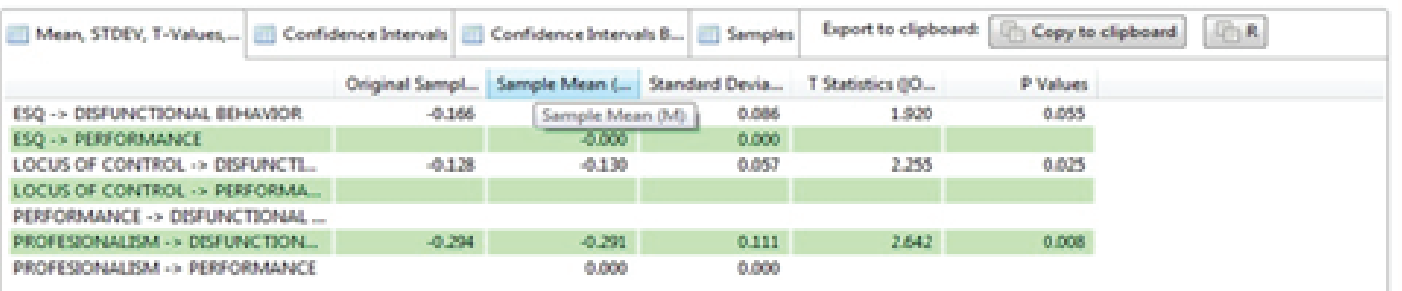

Figure 2: Path coefficient.

condition occurs because the models of intelligence that are now being developed in the world base their arguments on the scientific findings of the study and neuroscience research. Locus of control has positive influence on acceptance of dysfunctional audit behavior, meaning that the higher the locus of control, then it affects the acceptance of dysfunctional audit behavior.

Locus of control has positive influence on acceptance of dysfunctional audit behavior, meaning that the higher the locus of control, then it affects the acceptance of dysfunctional audit behavior. This condition occurs because individuals who have an external locus of control are individuals who believe that they can control events and results or outcomes, including dysfunctional behavior. These results support previous studies that show a strong and positive relationship between external locus of control individually with one's desires or intentions to use deception or manipulation to obtain personal objectives (Comer, 1985; [7]; Solar \& Bruehl, 1971). 
ESQ has a positive effect on the performance of auditors, meaning that the higher the ESQ, the higher the performance of auditors. This condition occurs because the ability to live the values and meanings, have self-awareness, and be flexible and adaptive is still limited to the ability of self that could someday disappear without trust and belief in a transcendental power that provides energy for humans.

Locus of control has positive effect on the performance of auditors, meaning that the higher the locus of control, then the higher the auditor's performance. These results support that internal locus of control tends to use pressure or urge a greater effort compared with individuals who have external locus of control when it is believed that the business appears or leads to reward (Rotter, 1990 as cited in [8]; Phares, 1968; Spector, 1982 as cited in [8]).

ESQ is not an antecedent variable in the relationship between employee performance with the acceptance of dysfunctional audit behavior. This indicates that the models of intelligence that are now being developed in the world base their arguments on the scientific findings of the study and neuroscience research. Ranging from conventional intelligence models (Intelligence Quotient), emotional intelligence (Emotional Quotient), up to the ultimate intelligence model of spiritual intelligence (Spiritual Quotient).

Locus of control is not an antecedent variable in the relationship between employee performance with the acceptance of dysfunctional audit behavior. Solar and Bruehl (1971 as cited in Donnelly et al., 2003) states that individuals who perform below their boss's expectations are likely to be engaged to perform dysfunctional behavior because they do not see themselves as able to achieve the goals needed to survive in a company through their own efforts, thus dysfunctional behavior is considered necessary in this situation. Locus of control plays a role in motivation and could reflect different motivations and different performance.

\section{Conclusion, Limitations, and Future Research}

ESQ has positive influence on acceptance of dysfunctional audit behavior, meaning that the higher the ESQ, the higher the acceptance of dysfunctional audit behavior. Locus of control has positive influence on acceptance of dysfunctional audit behavior, meaning that the higher the locus of control, then it affects the acceptance of dysfunctional audit behavior. ESQ has positive effect on the performance of auditors, meaning that the higher the ESQ, the higher the performance of auditors. Locus of control negatively affects the performance of auditors, meaning that the higher the ESQ, the lower 
the performance of the auditor. ESQ is not an antecedent variable in the relationship between employee performance with the acceptance of dysfunctional audit behavior. ESQ directly influences dysfunctional behavior, this is evidenced by the value of coefficient parameters of ESQ influence on the dysfunctional behavior of 0.2961 which is greater than the coefficient parameter of ESQ influence on dysfunctional behavior through the reception performance of employees of $\left(0.2961 \mathrm{x}-0.2152=-0.0637^{*}\right)$.

Limitations of this study are: It was not as easy to get back the questionnaire that was distributed as expected. It took two months to get all the questionnaires completed because of the duties and functions of the auditors in the Inspectorate are generally more out of the office. The use of this method, only using survey method with a questionnaire, allowed the occurrence of dishonesty in answering questions.

Suggestions in this study addressed to the Inspectorate and the public are as follows: 1. The use of other than survey methods, such as interview methods, can be used to obtain two-way communication with the subject and get honest answers from subjects. 2. Because this study contained incomplete questionnaire filling, further research is expected to check in advance the completeness of the answers on the questionnaire.

\section{References}

[1] Agus, Soekrisno. 1996. Auditing. Jakarta: Fakultas Ekonomi Universitas Indonesia, Salemba Empat.

[2] Akers. M.D \& Eaton. T.V. 2003. "Underreporting of Chargeable Time : The Impact of Gender and Characteristics OF under reporters." Journal of Managerial Issues 1.

[3] Arens, Alvin,A and James, K.L.1995 Auditing An Integrated Approach, 4th ed. New Jersey : Prentice Hall, Inc.

[4] Bluedorn, A.C. (1982), "A unified model of turnover from organizations", Human Relations, Vol. 35 No. 2.

[5] Brownel, P. 1982. Participation and Budgeting, Locus of Control and Organizational Effectiveness. The Accounting Review. Vol LVI (4

[6] Donnely, David P., Jeffrey J. Q, and David 0., 2003 "Auditor Acceptance of Dysfunctional Audit Behavior : An Explanatory Model Using Auditors' Personal Characteristics." Journal of Behavioral Research In Accounting: vol. 15.

[7] Gable, M., and F. Dangello. 1994. "Locus of Control, Machiavellianism, and Managerial Job Performance." Journal of Psychology 128.

[8] Hyatt, T., and D. Prawitt. 2001. "Does Congruence Between Audit Structure and Auditors Locus of Control Affect Job Performance?." The Accounting Review 76. IAI, 
Media Akuntansi No. 20/ th.IV./ 1997

[9] Iyer, V.M. (1998). "Characteristic of accounting firm alumni who benefit their former firm". Accounting Horizons (March).

[10] Rush R.H. and Harrel A. 1990. "The Impact of Personality Characteristic on The Turnover Behavior of Accounting Professional". Auditing: A Journal of Practice and Theory 9 (2).

[11] Soobaroyen, Teeroven dan Chelven Chengabroyan. (2005). Auditors' Perception of Time Budget Pressure, Premature Sign Offs and Under-reporting of Chargeable Time : Evidence from a Developing Country [On-line] http://www.aber.ac.uk.

[12] Tett, R.P. and Meyer, J.P. (1993), "Job satisfaction, organizational commitment, turnover intention, and turnover: path analyses based on meta-analytic findings", Personnel Psychology, Vol. 46 No. 2. 